\title{
Toward an Integrated Segment Reporting: Between Tradition and Innovation
}

\author{
Maria Gabriella Baldarelli ${ }^{1}$, Domenico Nicolo2*
}

1. Department DISA/ University of Bologna, Italy.

2. Department DIGIES/ University Mediterranea of Reggio Calabria, Italy.

\section{*Corresponding Author: Domenico Nicolo}

Abstract: This paper aims to focus on the contribution of the approach by segments to planning and reporting social and environmental performance along with economic and financial dimensions. After the review of the literature about stakeholder's theory and segment reporting, the paper analyse the logic underlying the technique of segmentation in the "space" and in the "time" for corporate reporting in theory and in practice.

Keywords: Environmental reporting, Integrated reporting, Social reporting, Segment reporting, Social segment reporting, Sustainability reporting.

Article Received: 25 Sept. 2019

Revised: 15 Oct. 2019

Accepted: 19 Oct. 2019

\section{Introduction}

In the literature relating to the stakeholder theory, the aspects of external reporting and accountability directed towards the outside were considered above all. Recently, with regards to management control, attention has shifted to the management of internal resources and the use of segment reporting to improve the ability to understand the causes of the company's economic and financial performance.

The focus on only economic and financial aspects seems to be integrated to consider the pressures that emerge from some challenges deriving from the economic-social system in which the company operates. We refer in particular to: the motivation of internal staff that often generates strong conflicts, the emergence of climate and environmental changes, theories concerning happiness, the civil and "prophetic" economy $[1,2]$.

These requests coming from the stakeholders urge companies to re-orient their management and to re-interpret traditional models and tools to make them suitable to direct management towards multidimensional objectives in the perspective of sustainability. This research in particular focuses on the segment reporting and how this can play a crucial role in the new challenges those companies are called to face.
Since the company is called to new challenges and therefore reinterpret its role in society, it must equip itself with new tools to make them fit for new functions. The manager's information needs have changed and therefore the tools must also change by changing the information content.

In this work we focus on one of these tools: segment reporting, which, when properly rethought, can play a crucial role in this, that is, in a management that involves environmental and social aspects. Some quantities that are particularly significant: the margin of environmental contribution; the added value, etc. In this perspective it is possible to think of a model for "integrated segment reporting".

\section{Research Design and Methodology}

This paper is based on a theoreticaldeductive methodology for the construction of a framework on segmentation and reporting by segments in the measurement, control and management of sustainability and the social and environmental impact of the activities of companies and public administrations. Since there are no companies or even public administrations that neither use this framework nor segment reporting with reference to non-financial information, it is 
not possible to analyze business cases or company samples. Although this paper aims at theoretical aims, it cannot be argued that it has no practical utility, since it constitutes a reference point for the practice for the purposes of monitoring and managing the company's sustainability and its social and environmental impact.

This paper aims to fill a gap in the literature: 1) defining a framework based on segmentation and re-composition (aggregation) of the operations and activities of companies and public administrations; 2) highlighting how the segment reporting, generally used by companies to provide information to management (internal financial reporting) and to stakeholders (external financial disclosure), can play a very important role in assessing, controlling and managing companies' sustainability and their social and environmental impact.

\section{Literature Review on Stakeholder Theory and Segment Reporting}

The stakeholder's theory identifies over time the presence of different and new types of stake to be included in it. In the past it was mainly about the stakeholders deriving from the market: customers, suppliers, competitors through which commercial exchanges took place the stakeholder's theory $[3,4,5,6,7,8]$.

This theory has many times been misunderstood with its initial outlining and often considered as a pretext not to respect the neutrality and the equity of treatment of those with interest in the business [9, 10]. Subsequently, this theory has enriched the map of stakeholders through new subjects that can be close together, such as: internal staff, collaborators, the local community and the political-institutional interlocutors of the territory.

Also, you can include those far away, including: distant communities that require basic necessities; war zones that indirectly prevent companies from accessing these markets; atmospheric phenomena such as the melting of polar ice caps. The latter are added to the previous ones and are considered important in relation to globalization and the objectives of sustainable development of the UN SDGs 2030 [11]. This expansion of the sphere of stakeholders challenges the company within itself to an increasingly radical change in decision-making processes but above all stakeholder engagement. Among the most evident aspects, we can mention: the progressive lack of relational goods [12] and the pressure to find methods to manage conflicts inside of the company. Moreover, the business - bearers of interests (stakeholders) relationship, goes from a theory based on conflict, which nevertheless must be present, to one based on collaboration among the various stakeholders [13, 9, 14, 15, 16].

A collaboration which rests on the common anthropological basis and that does not see the conflict per se extinguish itself; rather it takes advantage of the dissent as a means of bettering the relationship with the stakeholders. This is corroborated by the concept of the common good [17, 18, 19, 20] which contributes to orientate decisions of managers towards (perhaps) an internalisation of ethical principles [10] and the exercising of "virtues" too [18].

Despite the great importance in the area of management control to support decisions [21, $22,23,24,25,26]$, reporting by segments is generally examined briefly in management control manuals [27, 28, 29, 30]. This lack of scholarly attention is evidenced by the presence in Italy of very few monographic works that are dedicated to reporting by segments, which examines above all external communication tool [31, 32, 33, 34, 35].

The original function of reporting by segments is to satisfy the information needs of top management that is interested in measuring, with a high frequency (quarterly, monthly), the performance of the segments corresponding to the lines of business and / or geographical areas in which the company operates. Over time, it has also taken on an external communication function thanks to specific international accounting standards that have introduced the obligation for listed companies to publish reporting by segments (SFAS: 14 and 131; IAS 14 and 14-R, IFRS 8).

A substantial research area of studies has therefore developed internationally on segment reporting as a tool through which listed companies disclose the report by segments [36, 37, 38, 31, 39, 40, 41, 42, 43, $44,45,46,47]$. With the issuance of IFRS 8 (Operating Segment), the management approach is introduced, according to which 
the information by segment for stakeholders must be based on the same segmentation map that is used by management [35, 46, 49, $50,51,52,53,54]$. In literature there is a gap in the theorization of reporting by segments as a tool for environmental and social planning and reporting.

This paper aims to bridge this gap highlighting this function that can be fulfilled. Moreover, through the interim environmental and social reporting it possible focus on the social and environmental impact of the business operations over time highlighting the influence of the past, present and future of company performance. Segment reporting by geographical area and by line of business (LOB) supplies very useful information for planning and for management control.

From the financial point of view, measuring only the overall result, the losses of one or more segments do not emerge if they are lower than the profits generated by the others, because of reciprocal compensation. The same is for the environmental and social dimension of their performance. Therefore, companies need to set segment reporting so as to allow the separate measuring of financial and non-financial performance indicators for each of the dimensions of their performance.

Constant monitoring of the external variables of each geographical area is very important in order to estimate the so-called country-risk, which heavily influences the results and risk of subsidiaries and, consequently, of the entity as a whole. However, this need is also often felt by enterprises operating on a national level: frequently, indeed, different geographical areas within the same country have such strong differences from this point of view.

The analysis of the operating results and sources of operating risk of geographical segments is also necessary in order to evaluate the sustainability of competitive advantage and of the results of the entity as a whole. Indeed, a satisfactory overall economic result may hide a worsening of competitive performance and of the operating result of one or more segments which are crucial for the success of the overall strategy. Segmentation in "space", by geographical area (and by LOB), highlights the relationship among segments and between segments and external variables, but it provides a static view because it does not show up the relationship between the past, the present and the future of the enterprise and of their segment's performance.

For this reason, we also need to segment in terms of time: corporate and segment results must be measured and then analysed separately with reference to annual and infra- annual periods. Interim reporting by segment, thus, provides management and stakeholders with a unitary space-time perspective from which to analyse segment and corporate results.

This perspective is the only one that underlines the links among segments, between segments and environmental variables and conditions, between the results achieved and the expected segment and corporate results $[35,55]$. At first glance, this approach could be considered reductive, since it hides the unitary nature of corporate management in space and in time. However, the truth is exactly the opposite.

It is necessary to identify the parts making up a system in order to focus on the relationships of interdependence that reciprocally connect its subsystems and external variables, even in different time periods. If we look closely we can see that the current high level of turbulence affecting economic systems originates from these relationships. The rapid spread of ICT and the speeding up of international transactions combine to spread market turbulence ever more rapidly, like an epidemic, on a global scale.

It is as if the natural irregularity of national markets were added to by the effects of upheavals in distant countries. All of this results in a kind of "domino effect", which can be of unpredictable intensity and take unexpected directions, causing irregularity in the variables that influence entities' results and risks. There is also the influence of past events, whose effects, though diminishing over time, persist for many years: temporal interdependence is thus inextricably linked to spatial interdependence $[35,55]$.

As space-time management segmentation focuses on the relationships between corporate subsystems and between these subsystems and external variables, even in different time periods, it facilitates 
comprehension of the overall functioning of the system, of the results it produces and of the risks to which it is exposed.

\section{Integrating Segment Reporting with Social and Environmental Variable}

Segmentation of management activities and operations in "space", ie in segments (responsibility centres of various aggregation level, processes, operations, elementary activities) and in "time", ie with reference to fractions of the year (semester, quarter, month), and the subsequent aggregation of these segments in the "space" (systemic vision relating to the entity as a whole) and in the "time" (annual and multi-year sequential vision), provide essential information both for planning and management control for the analysis of results both for the reporting of the results to the management (internal reporting) and to the stakeholders (external reporting). This applies both to financial performance and to the sustainability and social and environmental impact of the activities of companies and public administrations. We suggest a first draft of social segment reporting scheme (Table 1 ).

Table1: Social segment reporting scheme

\begin{tabular}{|c|c|c|c|c|c|c|c|c|c|c|}
\hline \multirow{3}{*}{$\begin{array}{c}\begin{array}{c}\text { Social Segment } \\
\text { Reporting } \\
\text { (for each month, }\end{array} \\
\text { quarter, semester) }\end{array}$} & \multicolumn{8}{|c|}{ Geographical areas } & & \\
\hline & \multicolumn{3}{|c|}{ Italy } & \multicolumn{2}{|c|}{ EU } & \multicolumn{2}{|c|}{ USA } & \multirow{2}{*}{$\frac{\text { Asia }}{\mathrm{b}}$} & & \\
\hline & $\mathrm{a}$ & $\mathrm{b}$ & $\mathrm{c}$ & $\mathrm{a}$ & $\mathrm{e}$ & a & $\mathrm{d}$ & & & \\
\hline \multicolumn{11}{|l|}{ Sales } \\
\hline \multicolumn{11}{|l|}{$\begin{array}{c}\text { Costs of bought in goods } \\
\text { and services }\end{array}$} \\
\hline \multicolumn{11}{|l|}{ Value added } \\
\hline \multicolumn{11}{|l|}{ Depreciation } \\
\hline \multirow[t]{6}{*}{$\begin{array}{c}\text { Net Value Added } \\
\text { by Segments }\end{array}$} & & & & & & & & & \multicolumn{2}{|c|}{ Total value added } \\
\hline & & & & & & & & & \multicolumn{2}{|c|}{ Distribuited as follows: } \\
\hline & & & & & & & & & \multicolumn{2}{|c|}{ - Employee benefits } \\
\hline & & & & & & & & & \multicolumn{2}{|c|}{ - Interest to lenders } \\
\hline & & & & & & & & & - Taxes & \\
\hline & & & & & & & & & - Dividend & \\
\hline
\end{tabular}

Adopting a similar "by segments" approach it is also possible to report and manage the company's impact on the environment by comparing objectives and results, with high frequency in the year (monthly, quarterly). The research line suggested by this paper is to combine the social and environmental segment reporting in a single integrated segment reporting.

\section{Conclusions}

Define a framework on social reporting based on segmentation in "space" and "time" of the activities carried out by companies and public administrations in subsystems (or

\section{References}

1. Bruni L, Zamagni S (2004) Economia Civile. Efficienza, equità, felicità pubblica (Il Mulino, Bologna). segments) - centers of responsibility, processes, operations, individual elementary actions - (analytical vision) and the "spatial" and "temporal" aggregation of business segments considered as a unitary systemeven if composed of subsystems -teleologically oriented to evolve to last over time (synthesis vision).

This approach highlights how segment reporting is very useful, as well as in financial reporting, also as a management and reporting tool for the impact of corporate activity on its sustainability, on stakeholders, on the community and on the environment in the which companies operate.

2. Baldarelli MG (2005) Verso l'economia civile: una prospettiva economicoaziendale (Maggioli, Rimini). 
3. Freeman RE, Reed DL (1987) Stockholders and stakeholders: a new perspective on corporate governance, California Management Review, spring, 88-107.

4. Freeman RE (1984) Strategic Management: a stakeholder approach (Boston, Pitman).

5. Matacena A (1984) Impresa e ambiente. Il "bilancio sociale" (Bologna, CLUEB).

6. Vermiglio F (1984) Il bilancio sociale nel quadro evolutivo del sistema d'impresa (Messina).

7. Vermiglio F (2000) (a cura di) Nuovi strumenti di comunicazione aziendale. Confronto di esperienze in tema di bilancio sociale (G. Giappichelli, Torino).

8. Rusconi G (1988) Il bilancio sociale dell'impresa. Problemi e prospettive (Milano, Giuffrè).

9. Freeman E, Rusconi G, Dorigatti M (2007) (a cura di) Teoria degli stakeholder. Collana Persona, imprese e società (Milano, Franco Angeli).

10. Rusconi G (2018) Ethical Firm System and Stakeholder Management Theories: A possible convergence, European Management Review, 16-1.

11. Bebbington J, Unerman J (2018) Achieving the United Nations Sustainable Development Goals: an enabling role for accounting research. Accounting, Auditing \& Accountability Journal, 31(1): 2-24.

12. Gui B, Sugden R (2005) (eds.). Economics and social interactions. Accounting for interpersonal relations (Cambridge University Press, Cambridge).

13. Matacena A (2010) corporate social responsibility and accountability: some glosses, Baldarelli, M.G. (ed.), Civil Economy, Democracy, Transparency and Social and Environmental accounting research role (McGraw-Hill, Milano).

14. Rodrigo P, Arenas D (2008) Do employees care about CSR programs? A typology of employees according to their attitudes. Journal of Business Ethics, 83(2):265-283.

15. Passetti E, Cinquini L, Marelli A, Tenucci A (2014) Sustainability accounting in action: Lights and shadows in the Italian context. The British

Review, 46(3):295-308.

Accounting

16. Cinquini L, Passetti E, Tenucci A (2016) La sostenibilità ambientale in azienda: quale relazione tra disclosure volontaria e gestione interna? Management Control, 15-32.

17. Masini C (1988) Lavoro e risparmio, II rist. (UTET, Torino).

18. Cortright SA, Naughton MJ (2002) Rethinking the purpose of business. Interdisciplinary essays from the Catholic Social Tradition (University of Notre Dame Press, Notre Dame, Indiana).

19. Zamagni S (2007) L'Economia del bene comune (IdeEconomia, Città Nuova, Roma).

20. Catchpowle L, Smyth S (2016, September) Accounting and social movements: An exploration of critical accounting praxis. In Accounting Forum (40 (3): 220-234). Taylor \& Francis.

21. Bergamin Barbato M

Programmazione e controllo in un'ottica strategica (Torino, UTET).

22. Riccaboni A (1993) La misurazione della performance nei centri di profitto: critica agli strumenti tradizionali e nuovi orientamenti d'indagine (Padova, Cedam).

23. Amigoni F (1995) Le forme di reporting e l'analisi degli scostamenti, in F. Amigoni (a cura di), Misurazioni d'azienda. Programmazione e controllo (Giuffrè, Milano).

24. Ferraris Franceschi R Pianificazione e controllo, (I, C).

25. Marchi L (2009) Il processo di reporting, in Marasca S., Marchi L., Riccaboni A. (a cura di), Controllo di gestione. Metodologie e strumenti (Knowità, Arezzo).

26. Marasca S, Marchi L, Riccaboni A (2013) Controllo di gestione. Metodologie e strumenti (Knowità, Milano).

27. Saita M (1996) Programmazione e controllo (Milano, Giuffrè).

28. Brusa L (2000) Sistemi manageriali di programmazione e controllo (Milano, Giuffrè).

29. Burch JG (2000) Contabilità direzionale e controllo di gestione. Impatto delle nuove tecnologie (Egea, Milano). 
30. Horngren CT, Foster G, Datar SM (2002)Contabilità per la direzione (Isedi, Prentice Hall International).

31. Paris A (1999) Comunicazione d'impresa e report di segmenti operativi (Padova, Cedam,).

32. Angiola N (2004) IAS 14: Segment reporting. Interpretazione e applicazione (Franco Angeli, Milano).

33. Angiola N (2007) IFRS 8: Operating segment. Riflessioni sui nuovi orientamenti (Franco Angeli, Milano).

34. Fortuna F (2004) Il segmental reporting nel processo informativo d'impresa: comunicazione interna, esterna e creazione di valore (333) (FrancoAngeli, Milano).

35. Nicolò D (2009) Il reporting per segmenti e l'informativa settoriale secondo l'IFRS 8 (Milano, Giuffrè).

36. Emmanuel CR, Gray SJ (1977) Segmental disclosures and the segment identification problem, Accounting and Business Research, 37-50.

37. Emmanuel CR, Gray SJ (1978) Segmental disclosures by multibusiness multinational companies: A proposal, Accounting and Business Research, 169-177.

38. Emmanuel CR, Garrod N (1992) Segment reporting: international issues and evidence (Prentice Hall-ICAEW, HertfordShire).

39. Street DL, Nichols NB, Gray SJ (2000) Segment disclosures under SFAS 131: has business reporting improved? Accounting Horizons, 14:259-285.

40. Herrmann D, Thomas WB (2000) An analysis of segment disclosures under SFAS No. 131 and SFAS No. 14, Accounting Horizons, 14(3):287-302.

41. Thomas WT (2000) The value relevance of geographic segment earnings disclosure under SFAS 14, Journal of International Financial Management and Accounting, 11(3):133-155.

42. Giusepponi K (2000) L'informativa di bilancio sulle aree di gestione operativa e sui settori d'attività, (a cura di) L. Marchi, L'applicazione dei principi contabili nei bilanci delle imprese. Best practices della comunicazione economico-finanziaria (Il Sole 24 Ore, Milano).
43. Street DL, Nichols NB (2002) LOB and geographic segment disclosures: an analysis of the impact of IAS 14 revised, Journal of International Accounting Auditing \& Taxation, 11(2); 91-113.

44. Quagli A, Teodori C (2005) (a cura di). L'informativa volontaria per settori di attività (Milano, Franco Angeli).

45. Nicolò D (2006) Segment reporting and IAS 14: Toward a theory, Emerging Issues in International Accounting Conference "Emerging Issues in International Accounting and Business 2006", Proceedings 2, University of Padua 20(22):665-676 (PADOVA: CLEUP,).

46. Quagli A (2007) Le nuove regole per l'informativa di segmento (International Financial Reporting Standard n.8 Operating Segments), Revisione Contabile, 73.

47. Berger PG, Hann RN (2007) Segment profitability and the proprietary and agency costs of disclosure. The Accounting Review, 82(4):869-906.

48. Zambon S (2011) The managerialisation of financial reporting: an introduction to a destabilising accounting change, Financial Reporting, 3:5-16.

49. Bugeja M, Czernkowski R, Moran D (2012) Did IFRS 8 increase segment disclosure? Working Paper (University of Technology, Sydney, Australia).

50. Crawford L, Extance H, Helliar C, Power D (2012) Operating segments: The usefulness of IFRS 8 (ICAS - Institute of Chartered Accountants in Scotland, Edinburgh).

51. Mardini GL, Crawford D (2012) Power, The impact of IFRS 8 on disclosure practices of Jordanian listed companies, Journal of Accounting in Emerging Economies, 2(1):67-90.

52. Pisano S, Landriani L (2012) The Determinants of segment disclosures: an empirical analysis on italian listed companies, Financial Reporting, 1(1):113132.

53. Nichols N, Street D, Cerola S (2012) An analysis of the impact of adopting IFRS 8 on the segment disclosures of European blue-chip companies, Journal of International Accounting, Auditing, and Taxation, 21(2):79-105. 
54. Pardal P, Morais AI, Curto JD (2015) Competitive harm and business segment reporting under IFRS 8: evidence from European Union listed firms, EAA 38th Annual Congress, 28-30 apr, Glasgow.

55. Nicolò D (2018) Il reporting per segmenti nel controllo di gestione. Un'esperienza nel settore delle autolinee di trasporto pubblico. In: (a cura di): S. Corbella, L. Marchi, F. Rossignoli, Nuove frontiere Del reporting aziendale. La comunicazione agli stakeholder's tra vincoli normativi e attese informative. Collana Di Ragioneria Ed Economia Aziendale, 175-195 (MILANO: FrancoAngeli). 